\title{
DEVELOPMENT OF ECOPRENEURSHIP IN PRIMARY SCHOOL
}

\author{
Sani Aryanto ${ }^{1}$ and Ernawulan Syaodih ${ }^{2^{\star}}$ \\ ${ }^{1}$ S.Pd., Universitas Pendidikan Indonesia, Indonesia, sani.aryanto29@student.upi.edu \\ ${ }^{2}$ Dr. M.Pd., Universitas Pendidikan Indonesia, Indonesia, ernawulansy@upi.edu \\ ${ }^{*}$ Corresponding author
}

\begin{abstract}
Ecopreneurship is an idea that has not been explored by researchers explicitly and become a learning innovation in the $21^{\text {st }}$ century, but, implicitly this concept is believed that it has been implemented in some primary schools but no further research, therefore, this study aims to prove and to give the description of ecopreneurship development in primary school. This study used a qualitative approach with descriptive method. The subject of this research is 22 teachers in primary school. The results of this research showed that the development of ecopreneurship in primary school was integrated in the curriculum content in schools that have implications to the creation of intracurricular learning, extracurricular learning, and display room based on the ecopreneurship's concept. It is found that $81.2 \%$ of teachers have tried to apply the principles of ecology in classroom learning and $54.5 \%$ of teachers have tried to associate it with the principle of entrepreneurship. The result of this research became the basis for researchers in conducting further research. In addition, the result of this research is expected to be a reference for primary school teachers to develop current learning in $21^{\text {st }}$ century and it becomes a preventive effort, especially for Indonesian society in preparing them to face Indonesia Emas 2045.
\end{abstract}

Keywords: Ecopreneurship, Education in $21^{\text {st }}$ Century, Indonesia

\section{INTRODUCTION}

The $21^{\text {st }}$ century education becomes the reference of education in the world, including Indonesia. There are three basic skills in the implementation of $21^{\text {st }}$ century education, those are "(1) life and career skills, (2) learning and innovation skills, and (3) Information media and technology skills" (Trilling \& Fadel, 2009). One of the $21^{\text {st }}$ century skills which is interesting to be studied in the implementation of education in Indonesia today is a career skills that put forward the principles of entrepreneurship and learning innovation skills embodied in problem-based learning that focuses on ecological problems based on the condition of Indonesia which rich of Natural and Human Resources.

Indonesia is predicted to experience demographic bonus in 2030 and is expected to reach the golden age in 2045. According to Aryanto, (2016, p. 431) "In that period the nation's future generations are at a very productive and highly valuable point". So it needs to be managed and utilized properly in order to become a human character, smart, competitive. But if this demographic bonus cannot be properly managed, it will 
result in a demographic disaster. This is where the strategic role of education development is used, especially to anticipate the demographic disaster. "Education is an investment that has a strategic role in developing qualified human resources. Therefore, it is very important to reconstruct and reformulate the educational design that can support the creation of the Indonesian gold generation". (Dongoran, 2014). According to Grace (2016, p. 389) "The gold generation is the generation that makes changes and changes the state and self-esteem of the Indonesian people more precious in the eyes of the world". But are all these hopes accomplished? Because demographic bonuses can also turn into a demographic disaster if it isn 't attended seriously and periodically handling from all sides.

Indonesia is also faced with environmental problems caused by the imbalance of human behavior patterns in exploiting Natural Resources (SDA) without the processing effort. According to Wahyuni (2016) that Indonesia became the second largest country as the largest contributor of waste in the world. And it is an indicator that Indonesia is slumped in waste management that is not accompanied by ecological behavior. Therefore, comprehensive efforts of all parties, especially in the field of education. According Manulang (2013) "Generations that are expected to play an important role in 2045 are mainly students who are currently sitting in primary, junior and senior high schools, including those who are sitting in college". However, when prioritized from all levels of education, primary education in primary school has a strategic position in facing the gold generation in 2045. According to Aryanto (2016, p. 788) "The children in primary age is the right age to plant good character and it will become an efforts in facing the golden era of Indonesia in the $21^{\text {st }}$ century". And one of the solutions that can be done by the Indonesian people in welcoming the Indonesia Gold 2045 is the development of ecopreneurship in primary school.

Explicitly, there have not been many researches that specifically examine the development of ecopreneurship in primary schools, but research that is relevant to the principles of entepreneurship and ecological intelligence has been widely investigated. Research that is quite relevant to the development of ecopreneurship such as research conducted by Muhaimin (2014) which focuses on the development of ecological competence through a critical pedagogical aproach, which resulted in the cognitive, affective, and psychomotor aspects of significance. In addition, other research conducted by Aryanto (2016) focuses on developing the principle of edupreneurship in primary schools in an effort to create innovative and productive learning. Based on these two studies, researchers try to connect the concept of entrepreneurship and ecology into the concept of ecopreneurship that has been unwittingly implemented implicitly but there is no explicit knowledge. So the purpose of this study is to prove and provide an overview of the development of ecopreneurship in primary schools.

This research uses qualitative aproach through descriptive method. The researchers try to give contextual description through questionnaires, interviews, and analysis of some supporting documents in the implementation of education in the school. Researchers formulate the framework of operationalization of research and research stages, to develop propositions (Musfikon, 2012). Researchers attempted to provide contextual descriptions through interviews, documentation and questionnaires in 22 teachers at Laboraory Primary School of Indonesia University of Education in Tasikmalaya, so it can be seen that most teachers have implemented the concept of ecopreneurship in intracurricular and extracurricular learning implicitly. Quantitatively it can be seen $81.2 \%$ of teachers have tried to aply the principles of ecology in learning in the classroom and $54.5 \%$ of teachers have tried to associate it with the principle of entrepreneurship. The results of this study became the basis of researchers in conducting subsequent research, in addition the results of this study is expected to be a reference for primary school teachers in developing cutting-edge of $21^{\text {st }}$ century learning.

\section{ECOPRENEURSHIP IN THE PERSPECTIVE OF EDUCATION IN $21^{\text {st }}$ CENTURY}

Ecopreneurship comes from two keywords, including ecological intelligence and enterprenuership characters that are based on $21^{\text {st }}$ century educational framework. Ecopreneurship is expected to make learners who have the creativity, innovation and unyielding spirit like an entrepreneur balanced with ecological behavior, so as to maintain, utilize, and manage the natural environment wisely.

\subsection{Ecological Intelligence}

Khan (2010, p.13) in his book "Critical Pedagogy, Ecoliteracy, and Planetary Crisis" expressed his concern about the current state of the earth, he said "sound ethical foundation for the emerging global society and to help build a sustainable world based on respect for nature, universal human rights, economic justice, and a culture of peace ". Respect for nature is at the center of its attention in maintaining sustainability on this earth, therefore ecological intelligence is seen as an alternative in the creation of peace on earth where every human being is able to maintain a balance between himself and his environment. According to Fassbinder (2012, p.9) Ecopedagogy works strategically for the scientific and scientific benefits of scientific and technological changes. Alongside equitable and sustainable lines, while also reducing the sociocultural 
and environmental costs ". Supriatna (2016, p.24) explains that "the ecological intelligence that an individual possesses is based on knowledge, awareness, and life skills in harmony with nature's sustainability. An ecologically intelligent person is a person who understands that his or her behavior and actions affect not only himself and others but also the natural environment in which he lives. The intelligence is built by the understanding that the nature in which he lives must be kept in order to maintain the carrying capacity for the life of himself and others".

Ecological intelligence is seen as a form of social skill that should be owned by every human being, especially in maintaining sustainability, because according to Supriatna (2016, p.26) reveals that social intelligence becomes a basic part for a person in developing social skills. Social skills by Walker, Covlin, and Ramsey in (Matson, 2009) add that: "Social skills are behaviours that assist the child in coping with adapting to increasingly demanding environment". Goleman (2010) which explains ecological intelligence is defined as the integration of empathy, viewing the perspective of others, and cooperation, with understanding and respect for the natural system. The ecoligically literate person has the knowledge necessary to comprehend interrelatedness, and attitude of care or stewardship. Such a person would have the practical competence required to act on the basis of kowledge and feeling. Learning in $21^{\text {st }}$ century that can be developed through ecological intelligence is Critical thinking and Problem solving. Through environmental problems that occur, learners are trained to think critically and solve problems, so he can carry on his life.

\subsection{Enterpreneurship}

Entrepreneurship is the ability to create something new in the creative/ innovative and capable to take risks over the decision and carry it out as a result of his creation is best so that the expected added value can be achieved (Handayani, 2017). Entrepreneurship is believed to be made as "one of the competencies that must be achieved in Graduate Competency Standards, has been tested to contain the values of goodness that students should have" (Ulwiyah, 2012). Values of goodness that is contained have vision and mission, creative and innovative, dare to risk, spirited competition, able to see and create opportunity, fast response and fast movement, social soul and become generous. Entrepreneurship education is expected to prepare its graduates have high discipline, commitment, honest in acting and being, creative and innovative, risktaking attitudes, proactive attitude and independence (Aryanto, 2017).

Entrepreneurship becomes one of the characteristics in education of $21^{\text {st }}$ century especially in Life and Career skills, the following explanation can be seen through table 1.

Table 1: Life and Career skills

\begin{tabular}{l} 
Description \\
\hline 1. Flexibility and adaptability: Learners are able to adapt change and flexible in learning \\
and activities in groups \\
2. Have the initiative and can manage themselves: Learners are able to manage goals \\
and time, work independently and become learners who can manage themselves. \\
3. Social and intercultural interactions: Learners are able to interact and work effectively \\
with diverse groups. \\
4. Productivity and accountability: Learners are able to project and produce products. \\
5. Leadership and responsibility: Learners are able to lead their friends and be \\
responsible to the wider community.
\end{tabular}

Source: Trilling dan Fadel (2009)

Based on table 1, there are five points in life and career skills that show entrepreneurial behavior that becomes the main framework in developing ecopreneurship in primary school.

\section{RESULT AND DISCUSSION}

Ecopreneurship development in primary school is a form of $21^{\text {st }}$ century learning innovation. In the process of implementation, $21^{\text {st }}$ century learning has to elaborate, refine, analyze and evaluate their own ideas in order to improve and maximize creativity efforts (Pirto, 2011) so that it describes the soul of ecopreneur.

\subsection{Result}

This study aims to prove and to provide an overview of the development of ecopreneurship in primary school. The following levels of development can be seen through Figure 1. 
Enterpreneurship Based Intracurricular Learning Involvement of Entrepreneurs in learning Urgency of Entrepreneurship Education in.. Ecological Based Extracurricular Learning Ecological Based Intracurricular Learning

The Role of Government Teacher's Ekopreneurial Character Student's Ekopreneurial Character Evironmental Class Reuse, Recycle, and Reduce Environmental School Knowledge of Ecological Principles

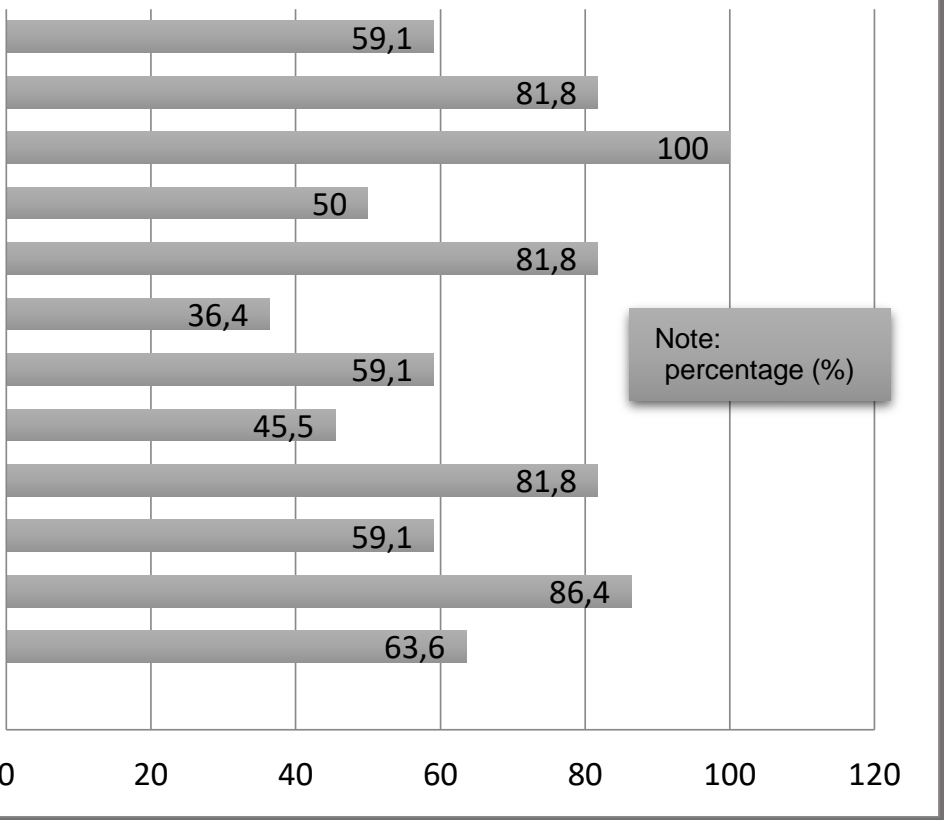

Figure 1: The Development of Ecopreneurship in Primary School

Based on figure 1, it can be seen that $63 \%$ of teachers are aware of the theoretical ecological concept although $27.3 \%$ of teachers cannot give detailed explanation regarding the concept of ecopreneurship, even $9.09 \%$ of teachers do not know and admit have never heard the term ecological intelligence, ecolitercy and ecopedagogy. However, this school is included in the category of schools that develop ecopreneurship when looking at the state of the school environment, curriculum development, and product / work of students that have been made, such as school equipments and accsessories. Therefore, $86.4 \%$ of respondents stated that this school applies the ecopreneurships' priciples. In addition, $59.1 \%$ of teachers perform reuse, recycle, and reduce in learning activities.

Most of students understand that ecopreneurs as part of the cognitive process, so only $45.5 \%$ of students are already beginning to reflect ecopreneuric behavior. Meanwhile, based on teacher reflection that there are $51.9 \%$ of teachers show the behavior of ecopreneur, so these matter become evaluations of principal in giving supervise to teacher.

It is unfortunate that the role of government as an important part in providing the strengthening of policies that support the development of ecopreneurship principles is still lacking, but it's only $36.4 \%$ of teachers stated that there is a government role in the development of ecopreneurship in primary schools.

The implementation of ecopreneurship learning that has been done by most of teachers in primary school is still partial, it means that there are teachers who only apply ecology-based learning, there are teachers who only apply entrepreneurship-based learning. Teachers who have applied ecological-based learning development as much as $81.8 \%$, while teachers who have applied entepreneurship-based learning as much as $59.1 \%$. However, some of them are implementing the principle of ecoprenuership intact but implicit.

\subsection{Discussion}

Ecopreneurship is an effort to make learners who have the character of abstinence, able to turn the challenge into an opportunity, independent, responsible, and have ecological behavior that can manage, utilize and maintain the surrounding natural environment. Ecopreneurship can be integrated in the content of formal and informal curricula, and its explorers can be seen in Figure 2. 


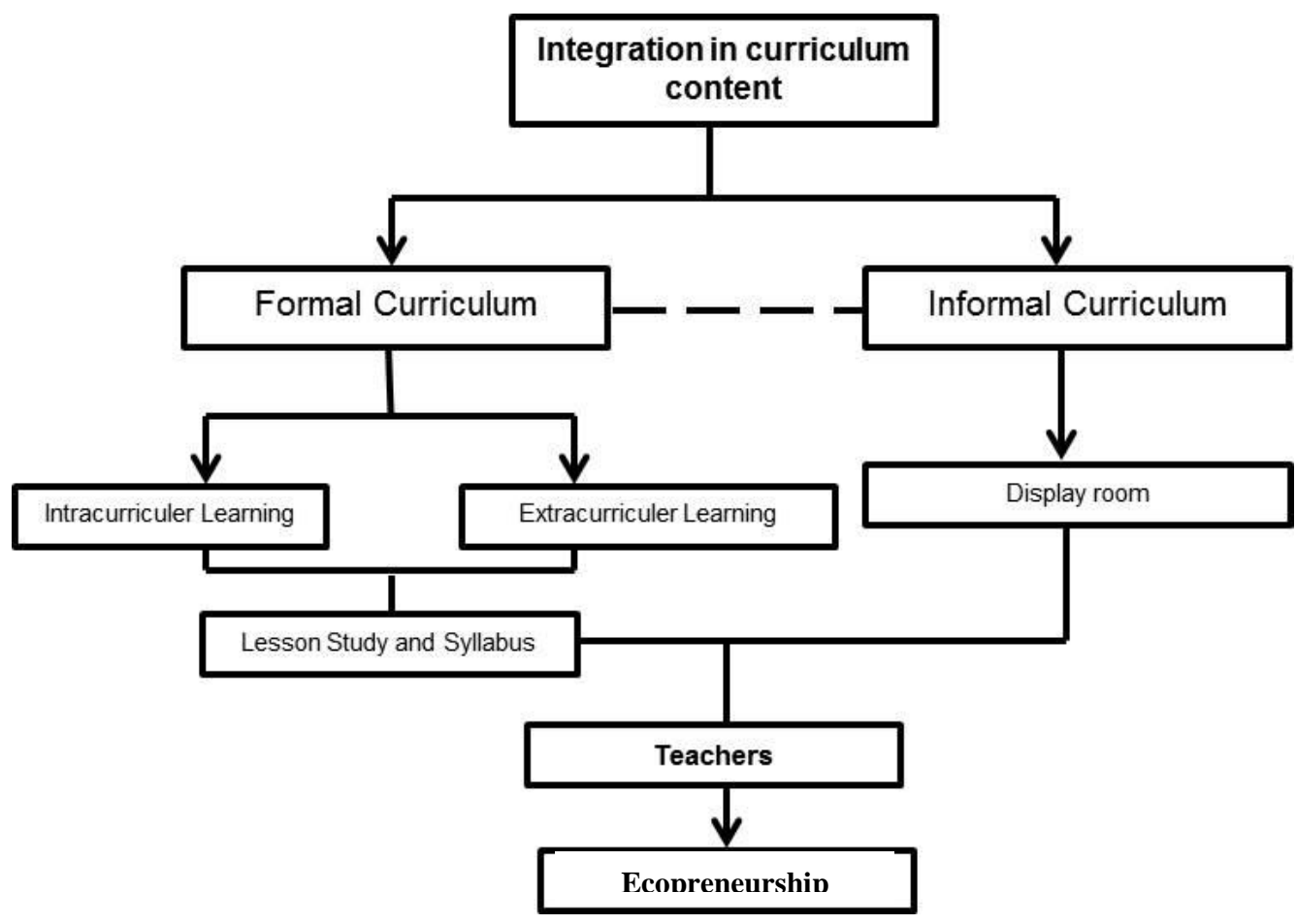

Figure 2: Stages of Ecopreneurship Development in Primary School

Based on figure 2, it can be seen that the development of ecopreneurship in primary school can be held through the integration of ecopreneurship content in the curriculum that has implications for intaracurricular, extracurricular and display room learning. Teachers are given flexibility in developing lesson study and syllabus that describe the principle of ecopreneurship.

Intracurricular learning activities that can be held in the development of ecopreneurship in primary school is a project based learning developed based on Creative Design Prosess (CDP) (Doppelt, 2005). Students are directed to create a simple product that has sale value which made by utilizing plastic waste around their school environment, and after that, the teacher can cooperate with parents in marketing their products through "Market Day" activity.

Development of extracurricular learning activities based on ecopreneurship can be held through hydroponic activity, and ecobrick. hydroponic activity is a transfer activity of planting media without using soil, where students are directed to grow vegetables effectively and efficiently by utilizing the former plastic bottle as a planting medium. The harvest is then sold that fit for students' desire. While ecobrick activity is the utilization of plastic waste collected periodically until in certain time and it is used as a product that has selling value. This activity is not only held by teachers, but they can cooperate with some part community such as environmentalists and entrepreneur community. While in the display room as a form of development of informal curriculum can be held by sticking poster and persuasive words which is talk about the principle of ecopreneurship.

\section{CONCLUSION}

Based on the research that has been conducted, it could be concluded that the development of ecopreneurship learning in primary school is still implicit. This means that teachers have begun to implement the development of ecopreneurship learning but they do not know the concept of the ecopreneurship. This can be seen based on the results of this research which stated that $63 \%$ of teachers know theory of ecological concepts even though $27.3 \%$ of teachers cannot provide the detailed explanation. However, the pattern of ecopreneurship development can be seen in the content of formal and informal curricula which are interpreted in intracurricular, extracurricular, and display room.

\section{ACKNOWLEDGMENT}

As one of the awardees of Indonesia Endowment Fund for Education (LPDP), I would like to express my gratitude to LPDP as institution giving fund to me to continue my study at Indonesia University of Education (UPI). Also, thanks to Dra. Ernawulan Syaodih, M.Pd for all the helps and supports in doing this reserach. 


\section{REFERENCE LIST}

Aryanto, S. (2017). Teacherpreneurship Based Local Wisdom as an Attempt to Develop The Character Of The $21^{\text {st }}$ Century Teachers in Primary Schools. Prossiding Basic Education And Early Childhood (ISBN: 978-602-61418-2-8) Vol. 2, No 1 p 630-634)

Aryanto, S. (2016). The Implementation of Edupreneurship Based on Local Wisdom in Primary School as an Effort to Prepare Indonesian Golden Era. Prossiding ICE 2016 UNM (ISBN: 978-602-71836-1-2) Vol. 1, No 1 p 787-793)

Aryanto, S. (2016). Development of Local-Based Studentpreneurship in Primary Schools as an Effort to Prepare the Golden Generation of 2045. Prossiding PGSD UNIKU (ISBN: 978-602-73053-1-1) Vol. 1, No 1 p 430-439)

Dongoran. (2014). The Paradigm Building the 2045 Golden Generation In The Perspective of Educational Philosophy. Journal of Tabularasa PPS UNIMED (ISSN: 1693-7732) Vol. 11, No 1 pp 61-76)

Doppelt, Y. (2005). Assessment of project based learning in a mechatronics context. Journal of Technology Education. Vol 16 no.2: 7-24

Fassbinder, SD. et.al. (2012). Greening the Academy Ecopedagogy Through the Liberal Arts . Rotterdam: Sence-Publisher.

Goleman, D. (2010). Ecological Intellegence, How Knowing The Hidden Impact of What We Buy can Change Everyting. Jakarta: PT Gramedia Pustaka Utama.

Handayani. (2017). Profile, Behavior and Condition Centers' Contribution towards Entrepreneurial Street Vendors: Case Study on the Central Street Vendors in Surabaya. Jurnal Tabularasa PPS UNIMED (ISSN: 2321-5925) Vol. 8, No 1 p 25-31)

Khan, R. (2010). Critical Pedagogy, Ecoliteracy and Palnetary Crisis. New York: Peter Lang Publishing

Manulang. (2013). Grand Design Character Education of Golden Generation 2045. Journal of Character Education. (ISSN: 1021-831) Vol. 1, No 3 p 1-14)

Matson, Jhony L. (2009). Social Behaviour and Skills in Children. London: Springer.

Musfikon. (2012). Educational Research Methods. Jakarta: PT. Prestasi Pustakaria

Piirto, J. (2011). Creativity for 21st Century Skills: How to Embed Creativity into the Curriculum. Rotterdam: Sense Publishers.

Supriatna, N. (2016). Ecopedagogy: Building Ecological Intelligence in Social Studies. Bandung: PT Remaja Rosdakarya.

Supriatna, N. (2016). Local Wisdom in Constructing Students' Ecoliteracy Through Ethnopedagogy and Ecopedagogy . UPI International Conference on Sociology Education (p 126-133) Publisher Atlantis Press.

Trilling, B. and Fadel, C. (2009). $21^{\text {st }}$ Century Skills, Learning for Life in our Times. San Fransisco: JosseyBass.

Ulwiyah. (2012). Integration of Entrepreneurship Values In The Classroom Learning Process To Create A Character Academic Entrepreneur. Journal of Proceedings of Semnas Competitive Advantages (ISBN: 978-602-99020-3-7) Vol. 1, No 2)

Wahyuni, T. (2016). Indonesia The Second Largest Contributor of Waste in The World. [Online]. Accessed from: http://www.cnnindonesia.com/gaya-hidup/20160222182308-277-112685/indonesiapenyumbang-sampah-plastik-terbesar-ke-dua-dunia/ 